IZA DP No. 4967

The Firing Cost Implications of Alternative Severance Pay Designs

Donald O. Parsons

May 2010 


\title{
The Firing Cost Implications of Alternative Severance Pay Designs
}

\author{
Donald O. Parsons \\ George Washington University \\ and IZA
}
Discussion Paper No. 4967
May 2010

IZA

P.O. Box 7240

53072 Bonn

Germany

Phone: +49-228-3894-0

Fax: +49-228-3894-180

E-mail: iza@iza.org

Any opinions expressed here are those of the author(s) and not those of IZA. Research published in this series may include views on policy, but the institute itself takes no institutional policy positions.

The Institute for the Study of Labor (IZA) in Bonn is a local and virtual international research center and a place of communication between science, politics and business. IZA is an independent nonprofit organization supported by Deutsche Post Foundation. The center is associated with the University of Bonn and offers a stimulating research environment through its international network, workshops and conferences, data service, project support, research visits and doctoral program. IZA engages in (i) original and internationally competitive research in all fields of labor economics, (ii) development of policy concepts, and (iii) dissemination of research results and concepts to the interested public.

IZA Discussion Papers often represent preliminary work and are circulated to encourage discussion. Citation of such a paper should account for its provisional character. A revised version may be available directly from the author. 
IZA Discussion Paper No. 4967

May 2010

\section{ABSTRACT}

\section{The Firing Cost Implications of Alternative Severance Pay Designs ${ }^{*}$}

Economists have concerns about the firing cost implications of mandated severance plans. Analysis reveals that predicted severance plan consequences depend critically on the precise structure of the plan. Whether governments mandate (i) severance insurance plans or (ii) severance savings plans is important; savings plans have no "firing cost" effects on employer layoff decisions. The firing cost implications of insurance plan are sensitive to the types of job separations that qualify a worker for benefits. Plans that pay benefits across all separations are functionally severance savings plans. The variety of plan types is illustrated using U.S. and international examples.

JEL Classification: J65, J41, J33

Keywords: job displacement, worker turnover, severance pay, firing costs

Corresponding author:

Donald O. Parsons

Economics Department

George Washington University

2115 G Street NW

Monroe Hall 368

Washington, DC 20052

USA

E-mail: dopars@gwu.edu

\footnotetext{
* An early version of this paper was prepared for presentation at the World Bank/IIASA/Ludwig Boltzmann Institute International Workshop on Severance Pay Reform: Toward Unemployment Savings and Retirement Accounts, Laxenberg/Vienna, November 7-8, 2003. I benefited greatly from discussions with Robert Holzmann and Milan Vodopivec as well as from the workshop presentations and related discussions.
} 


\section{Introduction}

Job displacement imposes heavy losses on some workers, especially long tenured ones, and many governments mandate service-linked severance benefits as a crude but administratively inexpensive form of consumption smoothing. ${ }^{1}$ Economists, however. have long expressed concerns about the "firing cost" implications of government mandated severance pay. ${ }^{2}$ Here I focus on alternative severance payout structures and argue that the firing cost implications of severance pay depend critically on the precise form of the mandate, and especially of benefit eligibility requirements.

The primary objective of this study is to explore the conditions under which mandated savings accounts are superior to mandated severance (insurance) pay as a mechanism for smoothing the consumption of workers permanently separated from their jobs. ${ }^{3}$ Other things equal, insurance is preferred to savings as a method of consumption smoothing in the face of large, low probability losses such as job displacement, but other things may not be equal. Especially if employers cannot reinsure severance insurance payouts, their job separation decisions may deviate from efficient levels. The implied firing cost distortions have of course been much discussed in the literature.

Severance savings plans-a simple form of unemployment insurance savings accounts with fixed benefits—have no firing cost consequences. ${ }^{4}$ This argument is a simple variant on Lazear's bonding "critique" of the firing cost effects of severance pay. Lazear (1990). In a multiperiod context, a severance insurance mandate can be "undone" by a more familiar mechanism, converting the insurance plan into a savings plan. Employer

\footnotetext{
${ }^{1}$ For excellent surveys of the U.S. displacement cost literature, see Jacobson, LaLonde, and Sullivan (1993), Fallick (1996), Kletzer (1998), and Farber (2005). For an international perspective, see Kuhn (2002).

The empirical firing cost literature is voluminous. Buechtemann (1992) provides an accessible introduction to the debate. See Parsons (2010a) for a recent review.

${ }^{3}$ There is a deeper political economy question that I do not confront in this positive analysis--whether firing cost distortions are an intended consequence of mandated severance plans. Efficiency questions aside, an alternative program that has the same consumption smoothing properties, but less substantial penalties for employer layoffs might not be preferred politically.

4 The insurance/savings distinction is a multiperiod variant on a bonding argument made by Lazear (1990), what has come to be known as the "Lazear critique" of the firing cost effects of severance pay.
} 
savings plans, notably in the form of private pension plans, are common, in the U.S. and worldwide.

Careful consideration of this simple case highlights the crucial importance of plan detail, not simply plan type (insurance or savings), in determining the implied firing costs with its implications for worker separations, accessions, and equilibrium employment. The key is that firing costs arise only to the extent the firm's total liabilities change with the displacement. To the extent firms are only postponing payout, not avoiding payout forever, firing costs are reduced. Of special importance then is the types of turnover that will trigger benefit payout. ${ }^{5}$ A savings plan with fair interest accrual carries no firing cost implications. The firing cost implications of severance insurance plans will converge on that of savings plans as the range of job separation "coverage" expands.

The analysis is theoretical but largely informal, and I draw a number of illustrative examples from the United States. ${ }^{6}$ The U.S. public unemployment insurance system is, of course, well-known. Less well known, voluntary severance pay plans are common, and are wholly private, provided directly by the employer or through the worker's union, Parsons (2005a, 2005b). Approximately one quarter of the workforce is covered by severance pay plans, with coverage sharply higher among office workers in large establishments, Bishow and Parsons (2006). A typical plan offers a week's pay for each year of service, up to a benefit or service maximum; plans vary greatly in the separations that qualify a worker for benefits, Parsons (2005c).

Both severance insurance and severance savings mandates are common abroad, though labels vary. For example, Heckman and Pagés (2004) label expected severance insurance expenditures as "indemnity costs," severance savings expenditures as "seniority pay." Parallels for severance savings accounts in the U.S. can be drawn with employer-

\footnotetext{
5 See Parsons (1977) for an introduction to turnover concepts.

6 A formal presentation and an extension to severance pay induced hiring costs can be found in Parsons (2010b).
} 
provided pension plans. ${ }^{7}$ The results provide a primer for the appropriate measurement of firing costs. The difficulty of empirically confirming plausible links between firing costs and employment behaviors in cross-national data sets may arise from inappropriate measurement of the independent variable, Addison and Teixeira (2003), Heckman and Pagés (2004), and Parsons (2010a).

Because of the often confusing terminology, especially across countries, I begin the analysis in Section II by defining key concepts. Then in Sections III, I provide brief, heuristic discussions of (i) the expected benefits of severance insurance and savings plans, and (ii) their firing cost implications. I argue that the distinction between severance insurance and severance savings accounts is theoretically important, but may be overdrawn. Severance insurance plans and severance savings plans are in fact poles on a continuum of severance plan structures, with varying degrees of insurance and firing costs. I illustrate the variety of possibilities with examples from U.S. severance plans in Section IV.

In Section V, I note that fringe benefit interdependencies may make it necessary to consider program clusters, not single programs, when assessing firing cost effects of alternative mandates. Again U.S. severance and pension policies provide examples. I then illustrate the value of the proposed program taxonomy in Section VI by assessing a rich set of program structures discussed at a recent international workshop on severance pay and savings accounts, Holzmann, Iyer, and Vodopivec (forthcoming). Section VII concludes.

\section{Job Separation Benefits: Some Definitions}

Job separation insurance comes in a variety of forms, with analysts in different countries often using different terminologies. To avoid confusion, I define a few key terms in this section. In carefully defining alternative programs, new programs are suggested. I also provide some warning of situations in which the terminology might conflict with common usage. Consider then the following program types:

\footnotetext{
7 The savings account aspect of defined contribution plans makes them an especially apt model to explore, although many large corporations in the United States as well as the social security system are defined benefit plans, with benefits unconnected to saving/asset activity.
} 
Unemployment insurance. Separation payments that depend on the separated worker's actual unemployment experience. These are typically periodic payments more or less coincident with the unfolding unemployment.

Severance pay (insurance) plan. Separation payments in excess of accrued wages, vacations, and accrued leave that do not depend on the worker's actual loss experience. These may be paid in a lump sum or as periodic payments.

Savings accounts. These involve contributions to an explicit worker asset account that can be disbursed to the worker under a variety of conditions; common restrictions include the following four types of funds:

Pensions or retirement savings accounts. These can take a variety of forms, but we focus here on defined contribution plans, essentially savings accounts with retirement as the obvious permissible disbursal contingency.

Unemployment insurance savings accounts. Savings plans with a limited set of permissible disbursal contingencies, including unemployment and retirement. Unemployment disbursement could be periodic, more or less coincident with the unfolding unemployment.

Severance savings accounts. Savings plans with a limited set of disbursal contingencies, including involuntary job separation (not unemployment) and retirement. These may be paid in a lump sum or as periodic payments following separation.

Provident funds. Savings plans with a relatively large number of permissible disbursal contingencies-job separation/unemployment, disability, retirement, and possibly house purchase or educational finance.

I argue below that the lines between these definitions are often blurred, and considerable care must be taken in assessing the individual characteristics of each plan.

I would conjecture, for example, that unemployment insurance programs in all but the most highly developed economies are in fact severance pay plans with periodic payments. Tracking a separated worker's unemployment experience is difficult in highly developed economies with small informal sectors. In economies with a large informal sectors and a substantial agricultural sector it is likely to be infeasible. Under these conditions, unemployment insurance systems are at best primary-sector unemployment insurance; workers released from a primary sector job may find their unemployment benefits stopped if they begin working again in the primary sector.

The distinction between pensions, which theoretically target only retirement needs, and severance savings accounts, which target job separation and retirement, is also likely to blur in practice. In the United States, for example, workers can put resources into a taxdeferred retirement savings account, most prominently 401(k) plans. If the worker separates 
from the employer, she may choose to roll-over the account into an alternative plan, or he can withdraw the funds for current use. ${ }^{8}$ The worker faces substantial economic penalties if she withdraws the funds - the funds are taxed as regular income and the worker is assessed a 10 percent penalty. Still the penalties are not so severe that withdrawal of funds is uncommon. The introduction of economic penalties for withdrawal essentially generates a continuum of possible combinations of severance savings accounts and pensions, with zero sanctions creating a "pure" severance savings account, and prohibitive sanctions a pure pension.

In the sections to follow I focus on two types of severance programs-insurance and savings-briefly reviewing the consumption smoothing benefits of each before turning to the impact on firing costs.

\section{Severance Insurance and Severance Savings: Consumption Smoothing and Firing Cost Consequences}

Alternative systems for providing scheduled benefits are not equally good at smoothing consumption over state and time in the face of permanent job displacement, which typically involves a small probability of a large loss. Insurance plans which smooth consumption across "states of nature" have an obvious advantage in this situation; by the definition of "small probability" of loss, the worker has a relatively large number (probability) of good states over which to smooth the potential losses. The ability to smooth consumption across time, savings plans, is naturally limited both early and late in the work life. Late in life, there is adequate time to build up a reasonable personal reserve, but the impact on retirement income grows as the remaining work life shrinks. In the absence of borrowing, shocks early in the work-life are also problematic for savings plans.

Costs are not identical under the two plans either. Of special concern, insurance plans often distort the incentives of the agents who enter into them, and job separation insurance is not likely to be an exception. A key concern is the "firing costs" distortions generated by mandated severance insurance programs; firing costs are likely to affect

\footnotetext{
8 For a readable summary of 401(k) plans, see http://invest-faq.com/articles/ret-plan-401k.html.
} 
separation rates directly and accessions and equilibrium employment indirectly. The direct effect on job separations is the focus of the following firing cost measure.

Firing cost $(F C)$ measurement. ${ }^{9}$ Consider a three period model $(\mathrm{t}=0,1,2)$ in which the risk neutral employer is considering the economic costs of laying off a worker. The firm will rationally consider both the current outlay-the lump sum severance payment B-as well as changes in future liabilities. Assume that the three periods involve two potential work periods $(t=0,1)$ and a retirement period $(t=2)$. Assume further that there are two reasons for separating from the firm in any period prior to retirement, involuntary (layoff) and voluntary (quit), and that the firm is currently considering an involuntary separation in period zero, perhaps because the firm is distressed. Looking ahead, the probability of a layoff in period 1 is $\sigma_{L}$ and of a quit is $\sigma_{Q}$, with $\sigma_{L}+\sigma_{Q}<1$. Any worker retained through the second period is retired, which may or may not induce benefits.

Formally we can denote the worker's expected firing costs at time 0 as $\boldsymbol{E}\left(\boldsymbol{F} \boldsymbol{C}_{0}\right)$, the sum of current severance benefits and the increment to future expected liabilities generated by the decision to release the worker, or

$$
E\left(C_{0}\right)=B+\Delta \Lambda
$$

where $\boldsymbol{B}$ denotes expected separation benefits paid to a worker of tenure by the firm, and $\boldsymbol{\Delta} \mathbf{\Lambda}$ denotes the increment (possibly negative) to expected firm liabilities beyond the cash payout.

Of particular note, the liability change may offset immediate severance payouts if the firm's future liabilities are reduced. If for example the employer's program is a savings account, with the employer holding the account on behalf of the worker and crediting the worker with contributions and accrued credit at market rates, then the impact of a payout is exactly offset by a reduction in liabilities—firing costs are zero:

$$
\Delta \Lambda=-B
$$

\footnotetext{
${ }^{9}$ This discussion is drawn from Parsons (2010b). A more complete discussion of the firing cost and hiring cost implications of severance mandates can be found there.
} 
The implications of retaining a worker and related liabilities need not be resolved at the time of layoff and, indeed, will be probabilistic if severance payouts are conditioned on stochastic separation events-severance insurance. If the firm retains the worker in the first period, the firm carries a liability equivalent to:

$\left.\Delta E \Lambda_{0}\right)=\sigma_{L} B, \quad$ if layoffs only are covered;

$\left.\Delta E \Lambda_{0}\right)=\sigma_{L} B+\sigma_{Q} B, \quad$ if layoffs and quits are covered; and

$\left.\Delta E \Lambda_{0}\right)=\sigma_{L} B+\sigma_{Q} B+1-\sigma_{L}-\sigma_{Q} B=B$, if layoffs, quits, and/or eventual retirement are covered.

Expected firing costs as a result of the severance mandate:

$\Delta E F C_{0}=1-\sigma_{L} B, \quad$ if layoffs only are covered;

$\Delta E F C_{0}=1-\sigma_{L}-\sigma_{Q} \boldsymbol{B}$, if layoffs and quits are covered,

$\Delta E F C_{0}=B-B=0, \quad$ if layoffs, quits, and/or eventual retirement are covered

The last option, (3c) and (4c), of course is equivalent to a savings account.

The idea is simple. The firm carries a liability corresponding to the separation insurance benefit into a period based on past service. In deciding whether to evade payment by retaining the worker, the firm must realize that it carries forward a liability that it may have to cover in the future. If it is offering severance insurance and currently faces a layoff situation that it does not expect will reoccur $\left(\sigma_{L}=0\right)$ firing costs will be equal to current severance payments. Otherwise, the greater the likelihood it will have to cover the severance pay liability in the future--either because the likelihood of layoff is large, or because voluntary quits or retirement are covered—-the smaller are firing costs.

\section{The Diversity of Severance Pay Plans in the U.S.: Firing Cost Implications}

The impact of severance pay plans on firing costs and hiring costs depends critically on the specific form of the plan, and especially on the benefit eligibility rules, which range from pure insurance plans-with benefit payout only for "involuntary separation without prejudice to the worker"- to pure savings plans, with benefit payout under every type of separation, voluntary or involuntary. Severance plans in the U.S. market illustrate the 
diversity of possibilities, and the care required in attributing firing costs and hiring costs to severance plans,

Severance pay plans in the United States are privately supplied, largely through the employer, but also through labor unions as part of collective bargaining agreements. ${ }^{10}$ In a voluntary contract between employers and workers, programs that limit deadweight losses are likely to emerge, and indeed there is little evidence that the modest levels of severance pay embedded in private U.S. severance plans seriously affect employer layoff strategies. ${ }^{11}$ Nonetheless these plans are useful in providing insights into provide important insights into the design and potential problems of more substantial, government mandated programs.

As market-determined financial instruments, severance plans take on a bewildering variety of forms. Key plan characteristics include the generosity of benefits, the form of payment, qualifying events for benefits, and the nature of benefit funding. Unfortunately the usual government sources, for example the Bureau of Labor Statistics' Employee Benefit Surveys (EBS), provide little information on severance pay structure in the United States, so we are forced to rely on private sources. A series of large scale surveys conducted by the National Industrial Conference Board provide abundant information on severance pay design prior to 1980, Parsons (2005a, 2005b), but to explore later developments we must rely on surveys conducted by private consulting firms, which tend to focus on compensation packages for upper level management workers.

Market-determined severance benefits tend to be modest. ${ }^{12}$ For example, an ambitious recent survey of 925 organizations in 2001 was conducted by Lee Hecht Harrison, a "career services company specializing in outplacement...." Lee Hecht Harrison report that,

\footnotetext{
10 For a history of the emergence and growth of private severance pay plans in the United States, see Parsons (2005a,2005b). Freedman (1978) provides some history of collectively bargained severance and SUB contracts.

11 Of course in the United States, employers have considerable flexibility to adjust plan payouts at any time. Employers in an especially serious downturn can reduce or even eliminate severance plan benefits. Unless prefunded, the plans are not covered by the regulations found in the Employee Retirement Income Security Act (ERISA) of 1974. Although pre-funding was unusual even prior to ERISA, it is plausible to conjecture that no employer would decide to do so today unless the firm has its own reasons to invoke ERISA..

12 See Parsons (2005c) for a more comprehensive review of severance generosity in the U.S.
} 
in organizations which pay severance strictly based on service, and not for example on age or level of position, almost three-quarters of all nonexempt workers and two-thirds of exempt workers below the "executive" level are paid on a scale that offers one week of pay per year of service or less, Table $1 A^{13}$ Only at the level of officer or senior executive would the median displaced worker receive two weeks of pay per year of service. In plans that involve more complex formulas, the bulk of both nonexempt and exempt employees below the executive level could expect to have such a service-linked plan, perhaps modified by age or title, Table 1B. Pita (1996) reports a similar level of payouts in collectively bargained agreements. Although a week of benefits per year of service is not a large sum, the capital value of benefits in the modal plan exceeds the maximum, "exhaustion" value of benefits in the U.S. public unemployment insurance program, Kodrzycki (1998). ${ }^{14}$

Of special interest here are the eligibility requirements for benefits, the range of job separation events that will qualify a worker for benefits. These vary greatly across plans. Some potentially important attributes of the plan do not affect firing costs. For example, whether the payout is limited to permanent separations or applied equally to temporary and permanent separations does not matter in a service-linear benefit system, assuming of course that the service "clock' restarted at each payout. ${ }^{15}$ In jobs with frequent temporary turnover, the severance resources would be paid out over time rather than at the time of permanent separation, but the total payouts would be identical, at least in a zero interest world. ${ }^{16}$

13 The terms "exempt" and "nonexempt" refer to categories of workers under the Fair Labor Standards Act of 1938. Various provisions, including government mandates for overtime premium pay, do not apply to all workers. Executives, administrators, and professionals are "exempt."

${ }_{14}$ In the U.S. public unemployment insurance system, which essentially offers a 50 percent replacement rate for up to 26 weeks, the capital value of severance exceeds that of the maximum (exhaustion-of-benefits) value of public unemployment insurance for workers with more than 13 years of tenure.

${ }_{15}$ With substantial interest rates, the employer would have to factor in the interest lost on early payouts as an additional cost of a temporary/permanent system.

${ }_{16}$ Little is certain in economic life, and even employers who pay out benefits only upon permanent separation must from time to time consider the conditions under which a "permanently" separated worker is rehired. Does the worker repay the severance, or restart the service clock at zero? Some employers give workers a choice. 
Other attributes of the plan, including the range of qualifying events for benefit status, are fundamental. Imagine a severance plan that paid out benefits for all conceivable reasons for job departure-such plans are not unknown in collective bargaining agreements. In this case, the severance plan is essentially a severance savings account, not insurance, and, like payouts in a worker savings account, the expense of current severance payout would be offset by a corresponding reduction in the expected future liability. The worker will receive the funds somehow, with payout at the time of layoff only one possibility. Behaviorally the rational employer's layoff decision would be unaffected by the existence of the severance plan. At the opposite pole is a severance plan that strictly limited payouts to "involuntary separations without prejudice" to the laid off worker. In the absence of separation effects on other parts of the compensation package, of which more will be said in the next section, the employer would rationally view the severance payment as a simple firing cost, and adjust his separation strategy accordingly.

Historically the qualifying events for severance benefit payments have varied substantially. The earliest formal plans, introduced on a large scale in the United States early in the Depression, were limited in scope; benefit status normally required that workers be involuntarily and permanently separated from the firm without prejudice to the worker, although small, notice plans were often associated with benign inefficiencies:

In forty-five of the sixty-six concerns [offering graduated plans] compensation is given only for permanent dismissal, while in the remainder it is granted for extended layoffs as well... Although many plans were originally adopted to facilitate necessary reductions in personnel, their scope has extended in a number of cases to include discharges for inefficiency, in order to eliminate individual misfits who might otherwise remain on the payroll for years. NICB [Brower] $(1937$, p.6)

Less commonly, graduated severance plans were used to compensate workers for other reasonable separations; for example approximately $10 \%$ of the 66 companies paid severance to those separated for physical incapacity, and some used the plans as a crude form of retirement pension. 
An NICB survey conducted twenty years later (1953) revealed a substantial expansion in the scope of qualifying events for benefits. Eligibility, as earlier, emphasized involuntary permanent separations initiated by the company:

All the plans provide severance pay for causes that might be considered beyond the individual's control. Among such reasons are elimination of the job, consolidation of departments, mergers, abandonment of plants, technological changes, and declining business activity. Thirty-two of the 103 plans analyzed, or about a third, grant severance pay only for such unavoidable layoffs. NICB [Forde and Brower] (1954, p.9)

However, the ancillary uses of severance pay to insure other involuntary events had expanded. "Forty plans, or nearly $40 \%$ of the total, grant severance pay for terminations due to disability....Only about one in ten plans in the 1942 survey included this as a reason." ${ }^{17}$ NICB [Forde and Brower] (1954, p.9) Negotiated union plans frequently did not require a specific departure event to make the individual eligible for severance--nineteen plans, primarily union-negotiated, even covered separation "for cause."

A Right Associates survey conducted in 1990 suggests that the range of qualifying events for severance benefits had again narrowed. Respondents with severance plans were asked if benefit eligibility is conditioned on one or more of the following qualifying events: reduction in force, elimination of position, discharge for performance, discharge for cause, discharge for disability, voluntary resignation, retirement with pension, and retirement without pension. The frequency of each is illustrated in Figure 1. The primary qualifying events are reduction in force and elimination of position, each of which is covered in essentially all plans. In approximately 40 percent of the plans, discharge for performance is covered; this separation category include workers making a good faith effort to do a job, but not succeeding at it, which could be viewed as an insurable event, one for which the employer is responsible. Conversely voluntary separations and discharges for cause are rarely

\footnotetext{
17 About $80 \%$ of the cooperating companies with retirement benefit plans do not give severance pay to employees whose services are terminated by retirement, except under certain circumstances." NICB [Forde and Brower] (1954, p.25)
} 
covered. ${ }^{18}$ Note also the absence of payments to retirees; U.S. plans are displacement insurance plans, not savings or provident funds, but approach retirement plans as the range of payouts beyond retirement increase and the probability of separating from the firm because of a covered event increases.

The important point is that the mix of insurance and savings in the U.S. severance structure, each with distinct implications for employer and worker behaviors, has varied over time. The inclusion of retirement as a qualifying event for severance payment pushes the instrument mix in the direction of a savings plan. Adding disability and, of greater consequence, voluntary turnover as qualifying events leaves little of the insurance aspect in place. In providing severance pay for job displacement, the employer's liability for other payouts is diminished, perhaps dollar for dollar.

\section{Individual Programs as Elements of a Policy Bundle}

The argument of the last section can be generalized; the impact on firing costs of any one program, considered in isolation, may give a misleading prediction of the overall effects on the economic calculations of workers and firms. This is especially clear in U.S. type systems in which a large share of "social insurance" costs are born by the employer, at least in the first instance. ${ }^{19}$ In the United States for example, severance pay is most common in large establishments and in workplaces covered by collective bargaining agreements, but these are the same workplaces that disproportionately offer defined benefit company pensions with lengthy vesting requirements. ${ }^{20}$

When considering job separation, worker vesting in a pension plan becomes a key parameter-how are worker pension rights affected by the separation? Maximum vesting

\footnotetext{
18 Eligibility rules in union contracts are apparently much more relaxed, with voluntary departures frequently covered. NICB [Forde and Brower] 1954, pp. 9-10. Voluntary turnover rates in major unions are of course rare.

${ }^{19}$ Those benefits actually valued by the employee are presumably ultimately born by the employee.

20 Defined benefit pensions are characterized by retirement benefits linked to previous salary, often in the last years of the employment relationship. Defined contribution plans are simply savings/investment vehicles with the magnitude of benefits a function of the success of plan investments. Vesting in a defined benefit plan refers to the right of benefit receipt upon retirement even if the worker departs the firm before retirement. In a defined contribution plan, it refers to the right to retain retirement plan assets.
} 
periods are now established by law in the United States by the Employee Retirement Income Security Act of 1974 (ERISA) and later amendments, but prior to 1974 firms were free to design the vesting rules they felt most advantageous. It was not uncommon for pensions to have, for example, cliff-vesting at 30 years of service. Workers who left the firm's employment with anything less than a lifetime of service could expect no pension. In such firms it would be reasonable for severance pay to be viewed as compensation for forfeited pension rights, and there is occasional evidence of managers who rationalized severance pay on that basis; severance "is granted to compensate older employees in some measure for the loss of their valuable seniority and pension rights and other company privileges which are the concomitant of long service." NICB (1943, p.4).

Of special note for "firing cost" measurement, management should rationally calculate firing costs as severance payments net of any future savings to pension plan obligations. In most cases the future effects of job separation on future firm liabilities would be negative. ${ }^{21}$ The pension cost offset to severance payments in the United States is not limited to companies with lengthy service requirements for vesting. Economists have long noted that the dependence of defined benefit plans on final years' salary makes the pension cost offset a function of the inflation level. Even moderate inflation rates impose an early departure penalty on the worker. From an employer viewpoint, this is a negative firing cost.

Although the details are peculiar to the United States, with its unusual dependence on the employer as provider of earnings insurance, the broader point is that the appropriate measurement of firing costs may extend well beyond severance pay, even when considered in detail. Permanent job separation may have consequences for the worker's fringe benefit package that are relevant for the employer's termination calculation.

\section{Firing Costs: Some International Evidence}

The variety of mandated separation pay plans internationally provides ample proof of the importance of a careful taxonomy of plans; some plans are likely to have the expected 
firing costs, while other may not. I illustrate this argument with program descriptions reported at a recent conference, Holzmann, lyer, and Vodopivec (forthcoming).

Hur (2003) examines the Korean severance pay system, and finds a savings plan, not an insurance plan. Korea mandates employer participation in a separation benefit plan that seems like a "severance pay" plan. ${ }^{22}$ However, the individual "asset" accounts accrue linearly with service, and are again paid out at the time of separation without any restrictions on the reason for departure. Even upon voluntary separation, the worker receives the money. Clearly this is a savings plan, not an insurance plan; the asset does not increase in value with an involuntary job separation; it is only paid out at that time. In deciding to fire a worker, the worker incurs no additional liabilities_barring default, the worker will receive these accrued benefits sometime, although perhaps not today. Of course, the firm may have an economic stake in when it pays its liabilities-now or at retirement-depending on interest accrual practices, Garibaldi and Pacelli (2003).

Recent Korean reforms, which appear to push the current severance pay plan toward retirement pensions, lay bare the need for careful thought on the freedoms workers should have to manage (or consume) their savings. At separation, should workers be required to roll over their accounts and not use the proceeds for current needs? Obviously conversion into a restricted, retirement-only plan eliminates any consumption smoothing in response to job displacement.

Prior to reform in 2003, the Austrian "severance pay reform" system provided an interesting example of limited firing costs, Koman, Schuh, and Weber (2005). Employers were required to pay out stipulated benefits upon separation initiated by the employer or by agreement between the employer and the worker. The latter presumably included mutually agreeable retirement. Not mandated were payments for voluntary (worker-initiated) separation. Expected firing costs in this case presumably reflect this exclusion. If voluntary

21 Indeed one motivation for ERISA (1974) was to regulate the employer's temptation to reduce pension costs by laying off workers just prior to pension vesting. 
turnover is low, the plan is essentially a savings program and firing costs are approximately zero. If voluntary turnover is high, the firm could anticipate avoiding this charge in time, and firing costs are equivalent to total separation benefits. Again the relevance of the savings account model to the mandated severance payment is an empirical question. In that respect, it is interesting to note that Koman, Schuh, and Weber (2003, p.257) report that, under pre-2003 mandates, "Employers had to make provisions in their accounts for at least half the severance pay entitlements that could fall due."

Following the recent reforms, the Austrian severance pay system is clearly a savings plan, not an insurance plan: "Entitlement...does not depend on the way of termination of the contract. Employers have to pay a contribution of 1.5377 percent of the payroll into a fund...from the first day on," Koman, Schuh, and Weber $\left(2005\right.$, p.258). ${ }^{23}$ The plan is perhaps best described as a severance/retirement savings account, because the worker can withdraw the money only upon involuntary separation or retirement: after three years of service,

[the] employee can choose between receiving her severance payment from the central funds at once, or saving her entitlement towards a future pension. The amount will not be paid out if the employee gives notice herself...[although] the acquired claim...remains (p.258).

The employer's payouts at separation are exactly offset by a reduction in future liabilities, so firing costs are now zero.

The effect of the reform on firing costs requires an understanding of pre-reform payout rules, those prior to 2003, which were unusual. In the Austrian system, a separated worker qualified for severance benefits if separated involuntarily from the firm or if retired, but not if the worker separated voluntarily. The system would provide an obvious disincentive for older workers to quit their jobs, which workers found unattractive. Postreform, job quitters also received the payout. Prior to the 2003 reform, the firing cost

\footnotetext{
${ }^{22}$ The original Korean word for this plan apparently does not distinguish severance from retirement, with neither being an especially informative label, as will become clearer shortly.

${ }^{23}$ The discussion is silent on the question of payouts upon the death of the worker, an alternative method of separation.
} 
measure would be positive for involuntarily separated workers, reflecting the probability that the worker, if retained, would voluntarily quit prior to retirement.

That is not to say that simple severance insurance plans, with their unavoidable firing cost implications, are unknown internationally. One apparently stark example of an insurance plan is that of the Philippines:

...severance pay is mandated for all regular workers...[It] is provided to individuals who are discharged due to redundancy or economic difficulties experienced by the firm; those who are dismissed due to gross misconduct are not entitled to severance benefits...the employment protection legislation requires a month of notification and severance pay equal to at least one month pay for every year of service in case of redundancy, and a half-month pay for each year of service in case of retrenchment to prevent losses in cases of closures. Esguerra (2003, pp.3-4).

Even in this case, benefit payments from private employers are far from automatic, so the firm's perceived or actual separation liabilities (firing costs) may be much less than the prescribed payouts. Indeed the conditionality of benefits on the precise reason for the separation itself apparently induces considerable litigation, Esguerra (2003, p.5).

Asher and Mukhopadhaya (2003), reviewing severance pay arrangements in six Asian countries, stress the importance of understanding labor law as well as the details of the separation plans in assessing consequences. In India, for example, they report that a permanently displaced worker is potentially eligible for two types of years-of-service-indexed separation benefits--retrenchment" benefits available only if job separation is involuntary, and "gratuity" benefits which are paid independent of the reason for job separation. Only the first would seem to generate "firing costs"; the second is a form of compulsory saving. Asher and Mukhopadhaya assert that neither are relevant in calculating firing costs in India. Labor laws severely restrict involuntary job separations, making a third mechanism, voluntary retirement schemes (VRS), a more appropriate measure of firing costs. VRS "are more expensive for the firms and...the economy as they have higher transaction cost than providing retrenchment benefits...[and] the flexibility in retaining the more productive staff may be less." Asher and Mukhopadhaya (2003, p.10)

Jaramillo and Saavedra (2005) report somewhat similar dual systems in a number of Latin American countries, with severance payments available to workers who "unjustly" lose 
their jobs, and "seniority payments" to workers who separate from their employer for any reason. "Just causes primarily include serious misdemeanor, dishonest behavior, sabotage, and considerable disrespectful attitudes... Only during the last decade some countriesnamely Argentina, Chile, Columbia, and Peru-have introduced a wider array of reasons, mainly those related to economic conditions of the firm, as just causes for layoff." (p.282). They appear to argue, however, that severance payments alone are a poor measure of firing-costs, and that one should look at the sum of severance and seniority payments to assess full costs. Venezuela, which mandates approximately 5 weeks of severance pay and 45 weeks of seniority pay for a separated worker with 20 years of tenure, and Columbia, which mandates 25 weeks of severance pay and 25 of seniority pay in the same circumstance, would be equivalent. Although this proposition is certainly amenable to empirical testing, simple economic theory would predict otherwise.

Although most of the examples illustrate how close severance insurance plans are to savings plans in their limited firing cost implications, the converse is also true. An interesting paper by Garibaldi and Pacelli (2003) illustrates the possibility that savings plans can have positive firing cost implications. They first note a recent Bank of Italy study, Brandolini and Torrini (2002), which makes the important point that, contrary to a recent OECD (1999) taxonomy, Italy does not have a severance plan, only a savings plan. The program in question, Trattamento di Fine Rapporto (TFR), involves "deferred wages that accrue to the worker upon separation for any reason." In short TFR is a savings plan, with restrictions on disbursement, which has no immediate firing cost implications. The authors then resurrect the firing cost concern by noting that interest payments in TFR accounts are arbitrarily small and that the firm can indeed reduce future liabilities by postponing payment. The exact magnitude of the interest rate effect is not easily assessed.

\section{Conclusion}

Involuntary permanent job separation frequently induces large economic losses, both in unemployment spells and in lower reemployment wages, and mandated severance payments have emerged worldwide as a public policy response. Concerns about the 
potentially large deadweight losses of mandated severance pay, however, have led to consideration of alternative job loss "insurance" approaches, including compulsory (severance) savings accounts, which with some regulatory elaboration can be transformed into unemployment insurance savings accounts.

Ideally insurance is the preferred method of consumption smoothing across risky states, especially in the face of the large, low-probability losses that characterize the permanent job separation of long tenured workers. However the choice between insurance and savings depends as well on distortions induced by the alternative programs. The standard scheduled severance insurance plan has a potentially important incentive effect on the employer's layoff decision, discouraging the efficient release of workers. One strong argument for a savings plan is that it would induce zero firing costs; the firm would appreciate that the worker will receive the assets in the account at some point and would not alter its layoff decision as a consequence. ${ }^{24}$

More intriguing perhaps is the result that emerges from a careful consideration of these two polar paradigms, that a continuum of policies lays between. Workers may separate for a variety of reasons which may or may not be covered by the severance plan mandate. The analysis reveals that care must be taken in assessing the impact of a separation plan on behavior. A simple analysis of program "types" may be misleading, because actual programs are often a probabilistic mixture of types. For example, the greater the variety of separation contingencies covered by a severance plan, the closer it comes to a savings plan. If severance is paid for all separation contingencies, including retirement, it is essentially a savings plan-the worker will receive the benefit in one form or another, and the employer has no incentive to maintain the worker on the payroll inefficiently.

The same calculation applies if the employer is holding a comprehensive set of distinct "insurance" packages for disability, retirement, etc. For example the traditional 30year cliff-vested pension plan in the United States presents the employer with a strong

\footnotetext{
${ }^{24}$ Again this assumes market rates of asset accrual with postponed withdrawals.
} 
incentive to layoff workers before they vest; severance pay, viewed as part of a benefit bundle, can be seen as an offset, compensating the worker for lost pension rights. Indeed the complexity of the appropriate measure of firing costs raises serious concerns about broad, cross-national studies of firing cost effects, and may explain the difficulties economists have had reliably estimating a priori plausible negative employment effects in such studies. 


\section{REFERENCES}

Addison, John, and Paulino Teixeira, "The Economics of Employment Protection," Journal of Labor Research, Vol. 24.1 (Winter 2003) 85-129.

Asher, Mukul G., and Pundarik Mukhopadhaya, "Severance Pay in Selected Asian Countires: A Survey," paper presented at the World Bank/IIASA/Ludwig Boltzmann Institute International Workshop on Severance Pay Reform: Toward Unemployment Savings and Retirement Accounts, Laxenberg/Vienna, November 7-8, 2003.

Bishow, John, and Donald O. Parsons, "Trends in Severance Pay Coverage in the United States, 1980-2001" (May 2004) Available at SSRN: http://ssrn.com/abstract=878144

Brandolini, A. and R. Torrini, "La Tutela del Rapporto di Lavoro Subordinato Secondo gli Indicatori dell'OCSE," mimeo Bank of Italy, 2002.

Buechtemann, C.F., ed. Employment Security and Labor Market Behavior: Interdisciplinary Approaches and International Evidence, Ithaca, NY: ILR press, Cornell University, 1992.

Esguerra, Jude, "Toward Unemployment Savings and Retirement accounts: Philippine Case," paper presented at the World Bank/IIASA/Ludwig Boltzmann Institute International Workshop on Severance Pay Reform: Toward Unemployment Savings and Retirement Accounts, Laxenberg/Vienna, November 7-8, 2003.

Fallick, Bruce C. "A Review of the Recent Empirical Literature on Displaced Workers," Industrial and Labor Relations Review, 50:1 (1996): 5-16.

Farber, Henry S., "What Do We Know about Job Loss in the United States? Evidence from the Displaced Workers Survey., 1984-2004," Princeton University Industrial Relations Section, Working Paper \#498, January 2005.

Freedman, Audrey, Security Bargains Reconsidered: SUB, Severance Pay, Guaranteed Work, The Conference Board Report No. 736, 1978.

Garibaldi, Pietro, and Lia Pacelli, "Mandatory Severance Payments in Italy: Do They Exist?" paper presented at the World Bank/IIASA/Ludwig Boltzmann Institute International Workshop on Severance Pay Reform: Toward Unemployment Savings and Retirement Accounts, Laxenberg/Vienna, November 7-8, 2003.

Heckman, James J., and Carmen Pagés, "Introduction," in Heckman and Pagés, eds., Law and Employment: Lessons from Latin America and the Caribbean, Chicago, The University of Chicago (2004): 1-107.

Holzmann Robert., Kripa Iyer and Milan Vodopivec, 2008. "Severance Pay Programs around the World: Rationale, Status, and Reforms." In Robert Holzmann and Milan Vodopivec, Mandated Severance Pay Programs: An International Perspective on Status, Concepts and Reforms, Washington, DC: World Bank (forthcoming).

Hur, Jai-Joon, "Korean Severance Pay Reform," paper presented at the World Bank/IIASA/Ludwig Boltzmann Institute International Workshop on Severance Pay Reform: Toward Unemployment Savings and Retirement Accounts, Laxenberg/Vienna, November 7-8, 2003.

Jacobson, Louis S., Robert J. LaLonde, Daniel G. Sullivan, The Costs of Worker Dislocation, Kalamazoo, MI: W.E. Upjohn Institute for Employment Research, 1993.

Jaramillo, Miguel, and Jaime Saavedra, "Severance Payment Programs in Latin America," Empirica Vol.32, (2005) 275-307

Kuhn, Peter, ed., Losing Work, Moving On: International Perspectives on Worker Displacement, W.E. Upjohn Institute for Employment Research, Kalamazoo, Michigan, 2002. 
Kletzer, Lori G. "Job Displacement," Journal of Economic Perspectives v12, n1 (Winter 1998): 115-36

Koman, Reinhard, Ulrich Schuh and Andrea Weber "The Austrian Severance Pay Reform: Toward A Funded Pension Pillar," Empirica Vol. 32 (2005) 255-274

Lazear, Edward P., "Job Security Provisions and Employment," Quarterly Journal of Economics 105 (August 1990), 699-726.

Lee Hecht Harrison, Severance and Separation Benefits: Bridges for Employees in Transition. Woodcliff Lake, NJ: Lee Hecht Harrison, 2001.

National Industrial Conference Board [F. Beatrice Brower], Dismissal Compensation, Studies in Personnel Policy, No. 1, New York, 1937. (1937)

National Industrial Conference Board [F. Beatrice Brower], Dismissal Compensation, Studies in Personnel Policy, No. 50, New York, 1943. (1943a)

National Industrial Conference Board [Lois E. Forde and F. Beatrice Brower], Severance Pay Plans, Studies in Personnel Policy No. 141, New York, National Industrial Conference Board, 1954. (1954).

OECD, "Employment Protection and Labour Market Performance," in Employment Outlook, Paris: OECD, 1999.

Parsons, Donald O., "Models of Labor Turnover: A Theoretical and Empirical Survey" in Research in Labor Economics, Ronald Ehrenberg, ed., 1977, 185-224.

Parsons, Donald O., "The Emergence of Private Job Displacement Insurance in the United States: Severance Pay Plans 1930-1954" (October 2005). Available at SSRN: http://ssrn.com/abstract=872331 (2005a)

Parsons, Donald O., "Private Job Displacement Insurance in the United States, 1954-1979: Expansion and Innovation" (November 2005). Available at SSRN: http://ssrn.com/abstract=872334 (2005b)

Parsons, Donald O., "Benefit Generosity in Voluntary Severance Plans: The U.S. Experience" (December 2005). Available at SSRN: http://ssrn.com/abstract $=877903$ (2005c).

Parsons, Donald O., "Mandated Severance Pay and Economic Performance: A Critical Review of the Evidence" mimeo George Washington University (Revised April 2010). $2010 \mathrm{a}$

Parsons, Donald O., "The Firm's Response to Severance Pay Mandates," mimeo George Washington University (Revised May 2010). 2010b

Pita, Cristina, "Advance Notice and Severance Pay Provisions in Contracts, Monthly Labor Review 119 (July 1996):

Right Associates, Severance: The Corporate Response. Philadelphia, PA: Right Associates, November 1990. 
Table 1

Panel A: Severance Benefit Generosity by Occupation, Organizations with Plan Based on Service Only, 2001 (in percent)

\begin{tabular}{|l|c|c|c|c|c|}
\hline & Officers & $\begin{array}{c}\text { Senior } \\
\text { Executives }\end{array}$ & Executives & Exempts & $\begin{array}{c}\text { Non- } \\
\text { Exempts }\end{array}$ \\
\hline $\begin{array}{l}\text { Weeks Pay/ } \\
\text { Year of Service }\end{array}$ & & & & & \\
\hline & & & & & \\
\hline$<1$ WEEK & 5 & 4 & 4 & 6 & 9 \\
\hline 1 WEEK & 43 & 44 & 47 & 60 & 65 \\
\hline 2 WEEKS & 28 & 28 & 32 & 30 & 23 \\
\hline 3 WEEKS & 5 & 5 & 5 & 3 & 2 \\
\hline 1 MONTH & 12 & 13 & 11 & 5 & 3 \\
\hline$>1$ MONTH & 14 & 11 & 7 & 2 & 1 \\
\hline
\end{tabular}

Source: Lee Hecht Harrison (2001, p.4). Column sums exceed one hundred percent because some respondents reported multiple formulas.

Panel B: Basis of Severance Calculations by Occupation, Organizations with Plan NOT Based on Service Only, 2001 (in percent)

\begin{tabular}{|l|c|c|c|c|c|}
\hline & Officers & $\begin{array}{c}\text { Senior } \\
\text { Executives }\end{array}$ & Executives & Exempts & $\begin{array}{c}\text { Non- } \\
\text { Exempts }\end{array}$ \\
\hline $\begin{array}{l}\text { Formula Includes } \\
\text { Years Of Service }\end{array}$ & 43 & 45 & 48 & 57 & 60 \\
\hline $\begin{array}{l}\text { Formula Includes } \\
\text { Salary/Grade Level }\end{array}$ & 34 & 36 & 39 & 45 & 40 \\
\hline $\begin{array}{l}\text { Formula Includes } \\
\text { Title/Level }\end{array}$ & 34 & 34 & 36 & 28 & 20 \\
\hline $\begin{array}{l}\text { Formula Includes } \\
\text { Age }\end{array}$ & 35 & 43 & 42 & 38 & 34 \\
\hline $\begin{array}{l}\text { Case By Case } \\
\text { Employment Agreement }\end{array}$ & 35 & 30 & 17 & 3 & 0 \\
\hline It Is Negotiated & 5 & 20 & 15 & 5 & 4 \\
\hline Flat Amount & 5 & 5 & 8 & 8 \\
\hline
\end{tabular}

Source: Lee Hecht Harrison (2001, p.4). Column sums exceed one hundred percent because some respondents reported multiple formulas. 
Figure 1

ELIGIBILITY CONDITIONS FOR SEVERANCE PAY, TOTAL AND BY ORG. SIZE, 1990 (RIGHT)

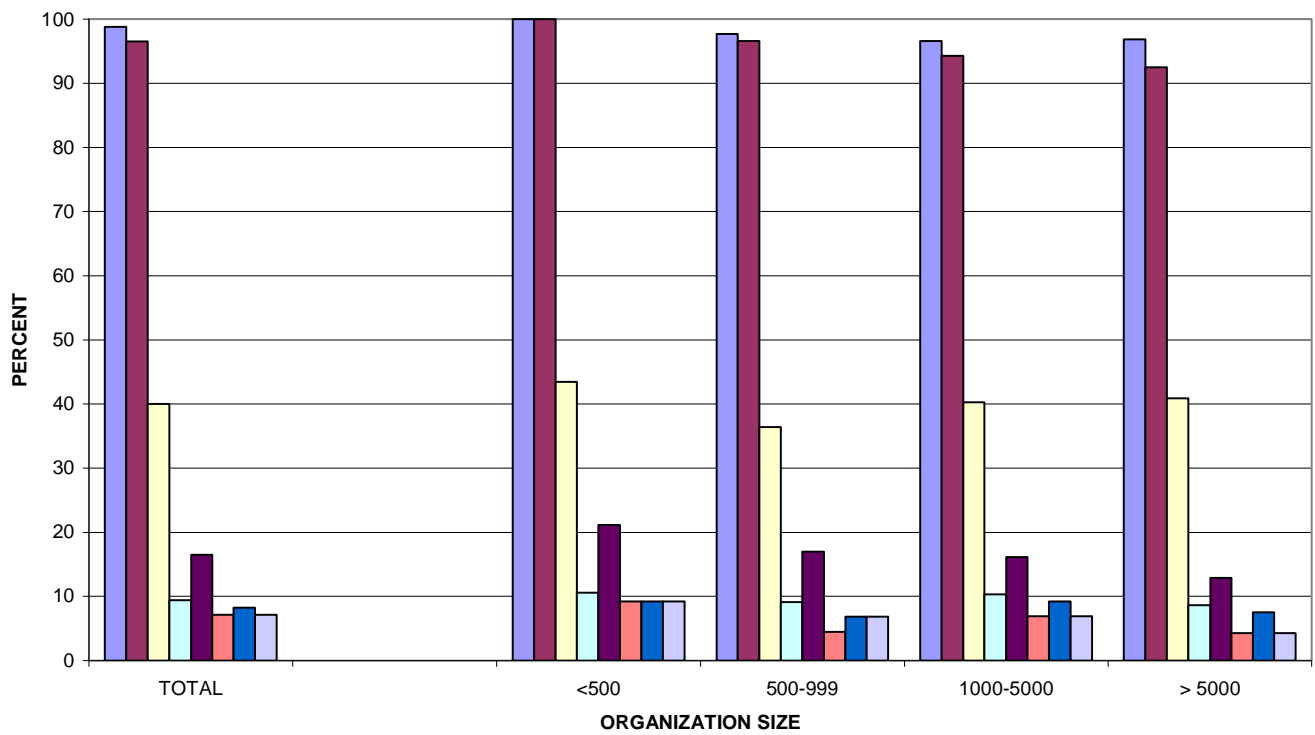

TREDUCTION IN FORCE GELIM OF POSITION DDISCHARGE, PERFORMANCE DDISCHARGE, CAUSE GDISABILITY GVOL.RESIGN. GRETIRE, PEN IRETIRE, NO PEN 